\title{
EFEKTIFITAS BERBAGAI BENTUK FLY TRAP DAN UMPAN DALAM PENGENDALIAN KEPADATAN LALAT PADA PEMBUANGAN SAMPAH JALAN BUDI LUHUR MEDAN TAHUN 2016
}

\author{
Nelson Tanjung \\ Jurusan Kesehatan Masyarakat Poltekkes Medan
}

\begin{abstract}
Abstrak
Lalat merupakan salah satu insekta (serangga) yang termasuk ordo diptera, mempunyai sepasang sayap berbentuk membran. Lalat juga merupakan spesies yang berperan dalam masalah kesehatan, yaitu sebagai vektor penularan penyakit saluran pencernaan seperti: kolera, typhus, disentri, dan lain-lain. Penyebaran penyakit oleh lalat dapat terjadi melalui kontak makanan dan minuman dimana tubuh lalat seperti pada kaki, mulut, sayapnya telah menempel bibit- bibit penyakit yang dibawanya dari tempat- tempat yang kotor, oleh karena itu perlu adanya pengendalian terhadap populasi lalat tersebut. Penggunaan flytrap diduga mempunyai pengaruh terhadap kepadatan populasi lalat, oleh sebab itu penelitian ini bertujuan untuk mengetahui pengaruh Flytrap terhadap kepadatan populasi lalat di pembuangan sampah Jalan Budi Luhur Medan. Dalam penelitian ini digunakan 3 unit Fly trap (bentuk kubus, segitiga dan bulat) dan 3 jenis umpan (Udang Basah, Insang Ikan dan Ampas Tebu) dengan ukuran masing-masing Fly trap $30 \mathrm{~cm} \times 30 \mathrm{~cm} \times 30 \mathrm{~cm}$, dimana diameter kerucut berukuran atas $5 \mathrm{~cm}$ dan bagian bawah berdiameter $10 \mathrm{~cm}$ sebagai jalan masuknya lalat dari bawah dengan tinggi kaki Flytrap $7 \mathrm{~cm}$, dengan kawat kasa sebagai dingding. Alat ini dipasang selama sembilan hari, sedangkan alat untuk mengukur kepadatan lalat menggunakan Flygrill. Dari hasil penelitian ditemukan bahwa dari ketiga bentuk Flytrap lalat lebih menyukai Flytrap yang berbentuk kubus dengan jumlah lalat yang masuk dari ketiga umpan ( udang basah, insang ikan dan ampas tebu ) adalah 1987 ekor dengan rata- rata 221 ekor. Dan umpan yang paling disukai lalat dari ketiga umpan (udang basah, insang ikan dan ampas tebu) tersebut adalah insang ikan 2294 ekor dengan rata-rata 255 ekor. Hasil penelitian ini diuji dengan uji statistik one way anova menunjukkan bahwa nilai $p=0,001<0,05$ dapat diartikan bahwa secara statistik H0 ditolak. Maka disimpulkan bahwa flytrap berbentuk kubus dan umpan insang ikan lebih efektif dalam pengendalian lalat. Saran dari penelitian ini diharapkan masyarakan dapat membuat atau menggunakan Flytrap untuk menurunkan kepadatan lalat khususnya di pemukiman yang berada di sekitar pembuangan sampah budi luhur, karena alat ini tidak menimbulkan bahaya dan sangat efektif dalam menangkap lalat.
\end{abstract}

Kata Kunci : Efektifitas, Pengendalian lalat, Fly trap

\section{PENDAHULUAN}

Dalam lingkungan pemukiman banyak jenis serangga yang harus dikendalikan walaupun tidak dapat diberantas secara tuntas antara lain adalah jenis lalat rumah. Lalat rumah merupakan jenis serangga yang suka hinggap ditempat-tempat yang kumuh misalnya di tempat pembuangan sampah, kotoran hewan dan kotoran manusia. Lalat disebut penyebar penyakit yang sangat serius karena setiap lalat hinggap di suatu tempat, kurang lebih 125.000 kuman yang jatuh ke tempat tersebut (Wikipedia, 2007). Menurut penelitian Suprapto (2003) pengendalian lalat dengan menggunakan perangkap $F l y$ Trap sangat efektif dalam menurunkan tingkat populasi kepadatan lalat dengan menggunakan umpan udang basah selama lima hari dengan jumlah yang tertangkap ialah 14.654 dan bila di persentasekan jumlah lalat yang tertangkap hari pertama $100 \%$, hari kedua $60,31 \%$, hari ketiga $56,02 \%$, hari keempat $51,43 \%$, hari ke lima $42,25 \%$. Menurut Aini (2000) penggunaan Fly Trap dengan umpan ampas tebu sangat efektif dalam menurunkan tingkat populasi kepadatan lalat dengan jumlah dimana jumlah yang sangat padat $42,31 \%$ menjadi $0,00 \%$, padat $46,15 \%$ menjadi $30,77 \%$ yang dilakukan di tiap rumah penduduk.

Survei awal peneliti dilakukan pada hari rabu tanggal 27 april 2016 pada tempat Sampah jalan Budi Luhur yang jaraknya kurang lebih 2 meter dari penjualan bakso dan perumahan penduduk dengan mengukur kepadatan lalat dengan menggunakan Flygrill pengukuran dilakukan 10 kali pengukuran dengan sekali pengukuran yaitu 30 detik dan hasil pengukuranya yaitu $(17,20,25,18$, $10,12,13,19,20,18)$ dan 5 skor yang paling tinggi di jumlahkan dan di bagi 5 maka didapat $(25+22+20+19+18)$ / $5=104 / 5=20,8$ dengan hasil yang diperoleh 20,8 yang artinya diatas 20 yaitu jika diatas 20 itu menyatakan bahwa populasi lalat sangat padat, dan perlu dilakukan pengamanan dan pengendalian lalat. Kehidupan lalat rumah disekitar rumah penduduk merupakan suatu hal yang sudah biasa, namun dilihat dari aspek kesehatan lingkungan perlu mendapat perhatian dan perlu 
dikendalikan dengan melak ukan penyemprotan pestisida dan dengan pembuatan perangkap lalat (Fly trap) sehingga lalat tersebut tidak menjadi penyebar penyakit pada penduduk disekitarnya.

Berdasarkan uraian diatas maka penulis tertarik untuk melakukan penelitian bagaimana efektifitas berbagai perangkap lalat dan umpan dalam pengendalian kepadatan lalat di tempat pembuangan sampah Budi luhur tahun 2016. Berdasarkan uraian latar belakang diatas, maka rumusan masalah adalah bagaimana efektifitas berbagai perangkap lalat (Fly Trap) dan umpan dalam pengendalian kepadatan lalat. Tujuan penelitian ini adalah untuk mengetahui efektifitas berbagai Fly Trap dan umpan dalam pengendalian kepadatan lalat.

\section{METODE}

Jenis penelitian ini adalah eksperimen dengan tujuan untuk melihat efektifitas berbagai jenis perangkap lalat (berbentuk kubus, segitiga dan bulat) dengan berbagai jenis umpan (Udang basah, insang ikan dan ampas tebu) dalam pengendalian lalat.

Rancangan penelelitian saya post test only desain yaitu

Eksperimen

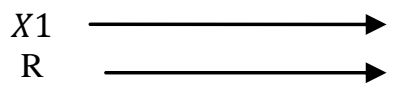

Keterangan :

$\mathrm{X} 1$ = berbagai fly trap (berbentuk kubus, segitiga, dan bulat) dan berbagai umpan (Udang basah,insang ikan dan ampas tebu)

$\mathrm{O} 2$ = jumlah lalat yang masuk

$\mathrm{R}$ = Pengulangan $\mathrm{a} /$ replikasi selama 3 kali

\section{Lokasi Penelitian}

Lokasi penelitian dilaksanakan di pembuangan sampah jalan Budi Luhur Kelurahan Dwikora Kecamatan Medan Helvetia. Alasan dipilihnya lokasi penelitian ini adalah di pembuangan sampah Budi Luhur populasi lalatnya sangat padat, dekat dengan penjualan bakso dan warung kopi dan dekat dengan pemukiman warga. Waktu pelaksanaan penelitian dilakukan mulai bulan JanuariAgustus tahun 2016. Objek penelitian ini adalah lalat, sehubungan dengan peranannya sebagai vektor penyakit terutama penyakit-penyakit pada saluran pencernaan seperti, kolera disentri, diare typhoid dan parasit cacing.

Alat
1. Gergaji
2. Martil
3. Meter

\section{Bahan}

1. Kawat kasa

2. Paku

3. Udang basah, insang ikan, dan ampas tebu

\section{Prosedur/Cara Kerja}

\section{Tahap persiapan}

Pada tahap ini dipersiapkan peralatan dan bahan sebagai berikut :
1. Membuat desain perangkap lalat (Fly trap) yang dibuat dari kawat.

2. Menyiapkan daftar isian pengukuran kepadatan lalat dari berbagai perangkap lalat (Fly trap).

3. Menyiapkan berbagai umpan seperti udang basah, insang ikan dan ampas tebu

\section{Tahap Pelaksanaan Penelitian Pengumpulan Data}

Untuk mendapatkan data dari tingkat kepadatan populasi lalat maka peneliti melakukan pengukuran kepadatan lalat sebelum meletakkan Fly trap di daerah yang akan dilakukan penelitian dengan menggunakan Flygrill. Angka rata-rata dari hasil pengukuran tingkat kepadatan lalat ini merupakan (indek) populasi dalam satu lokasi tertentu.

Setelah diketahui hasil pengukuran tingkat kepadatan lalat maka dipasang tiga unit Fly trap dengan tiga kali pengulangan, lalat yang tertangkap dihitung dan dimasukkan kedalam tabel sehingga dapat menggambarkan jumlah lalat yang tertangkap dan dengan mudah dapat menilai jenis Fly trap apa yang paling di sukai lalat danpjessi\$esmpan yang mana yang paling disukai lalat dan yangPidak di sukai lalat.

$$
\mathrm{R} 1,2,3
$$

\section{Tehnik Analisa Data} berikut:

Analisa data dilakukan dengan cara sebagai

1. Analisa Univariat

Untuk memperoleh informasi tentang kategori dari masing-masing variabel dependen dan independen.

2. Analisa Bivariat

Untuk mengetahui apakah ada perbedaan antara berbagai Fly trap (kubus, segitiga dan bulat) dan berbagai umpan ( udang basah, insang ikan dan ampas tebu) dengan jumlah lalat yang masuk dalam Fly trap tersebut dengan menggunakan uji one way anova menghasilkan nilai $\mathrm{P}<0,05$ dan uji Tukey untuk melihat perangkap dan umpan yang paling efektif dalam pengendalian lalat.

HASIL

1. Jumlah Lalat Yang Terperangkap Dengan Menggunakan Fly Trap Berbentuk Kubus Dengan Umpan Udang Basah, Insang Ikan Dan Ampas Tebu

Tabel 4.1 Hasil pengamatan jumlah lalat yang terperangkap pada fly trap berbentuk kubus

\begin{tabular}{|c|c|c|c|}
\hline Umpan & $\begin{array}{c}\text { Hari dan } \\
\text { pengulangan }\end{array}$ & $\begin{array}{c}\text { Jumlah } \\
\text { lalat }\end{array}$ & Rata-rata \\
\hline \multirow{3}{*}{$\begin{array}{c}\text { Udang } \\
\text { basah }\end{array}$} & $\begin{array}{c}\text { Hari 1- } \\
\text { pengulangan 1 }\end{array}$ & 166 & \multirow{2}{*}{$440 / 3=147$} \\
\cline { 2 - 3 } & $\begin{array}{c}\text { Hari 2- } \\
\text { pengulangan 2 }\end{array}$ & 124 & \\
\cline { 2 - 3 } & $\begin{array}{c}\text { Hari 3- } \\
\text { pengulangan 3 }\end{array}$ & 150 & \\
\hline
\end{tabular}




\begin{tabular}{|c|c|c|c|}
\hline \multirow{3}{*}{$\begin{array}{c}\text { Insang } \\
\text { ikan }\end{array}$} & $\begin{array}{c}\text { Hari 4- } \\
\text { pengulangan 1 }\end{array}$ & 540 & \multirow{2}{*}{$1144 / 3=311$} \\
\cline { 2 - 3 } & $\begin{array}{c}\text { Hari 5- } \\
\text { pengulangan 2 }\end{array}$ & 365 & \multirow{2}{*}{ 347/3=116 } \\
\cline { 2 - 3 } & $\begin{array}{c}\text { Hari 6- } \\
\text { pengulangan 3 }\end{array}$ & 239 & \\
\hline \multirow{2}{*}{$\begin{array}{c}\text { Ampas } \\
\text { tebu }\end{array}$} & $\begin{array}{c}\text { Hari 7- } \\
\text { pengulangan 1 }\end{array}$ & 104 & \\
\cline { 2 - 3 } & $\begin{array}{c}\text { Hari 8- } \\
\text { pengulangan 2 }\end{array}$ & 120 & \\
\cline { 2 - 3 } & $\begin{array}{c}\text { Hari 9- } \\
\text { pengulangan 3 }\end{array}$ & 123 & \\
\hline
\end{tabular}

Berdasarkan tabel 4.1 dapat di lihat bahwa ratarata Fly trap berbentuk kubus dengan umpan udang basah adalah 147 ekor pada hari ke 1- hari ke 3, pada hari ke 4s/d ke-6 dengan insang ikan rata-rata yang diperoleh 311 ekor, sedangkan hari ke 7s/d ke- 9 dengan umpan ampas tebu di dapat rata-rata sebanyak 116 ekor.

2. Jumlah Lalat Yang Terperangkap Dengan Menggunakan Fly trap Berbentuk Segitiga Dengan Umpan Udang Basah, Insang Ikan Dan Ampas Tebu

Tabel 4.2 Hasil pengamatan jumlah lalat yang terperangkap pada Fly trap berbentuk segitiga

\begin{tabular}{|c|c|c|c|}
\hline Umpan & $\begin{array}{c}\text { Hari dan } \\
\text { pengulangan }\end{array}$ & $\begin{array}{c}\text { Jumlah } \\
\text { lalat }\end{array}$ & Rata-rata \\
\hline \multirow[t]{3}{*}{$\begin{array}{l}\text { Udang } \\
\text { basah }\end{array}$} & $\begin{array}{c}\text { Hari 1- } \\
\text { pengulangan } 1\end{array}$ & 145 & \multirow[t]{3}{*}{$367 / 3=122$} \\
\hline & $\begin{array}{c}\text { Hari 2- } \\
\text { pengulangan } 2\end{array}$ & 120 & \\
\hline & $\begin{array}{c}\text { Hari 3- } \\
\text { pengulangan } 3\end{array}$ & 102 & \\
\hline \multirow{3}{*}{$\begin{array}{c}\text { Insang } \\
\text { ikan }\end{array}$} & $\begin{array}{c}\text { Hari 4- } \\
\text { pengulangan 1 }\end{array}$ & 249 & \multirow[t]{3}{*}{$632 / 3=211$} \\
\hline & $\begin{array}{c}\text { Hari 5- } \\
\text { pengulangan } 2\end{array}$ & 237 & \\
\hline & $\begin{array}{c}\text { Hari 6- } \\
\text { pengulangan } 3 \\
\end{array}$ & 146 & \\
\hline \multirow[t]{3}{*}{$\begin{array}{c}\text { Ampas } \\
\text { tebu }\end{array}$} & $\begin{array}{c}\text { Hari 7- } \\
\text { pengulangan } 1\end{array}$ & 124 & \multirow[t]{3}{*}{$308 / 3=103$} \\
\hline & $\begin{array}{c}\text { Hari 8- } \\
\text { pengulangan } 2\end{array}$ & 89 & \\
\hline & $\begin{array}{c}\text { Hari 9- } \\
\text { pengulangan } 3\end{array}$ & 95 & \\
\hline
\end{tabular}

Berdasarkan tabel 4.2 menunjukkan bahwa ratarata jumlah lalat yang masuk ke Fly trap yang berbentuk segitiga dengan umpan udang basah adalah 122 ekor yaitu pada hari ke-1 s/d ke 3, pada hari ke-4 s/d ke-6 dengan umpan insang ikan rata-rata yang diperoleh sebanyak 211 ekor, sedangkan dengan menggunakan ampas tebu yang dilakukan pada hari ke-7 s/d 9 rata- ratanya yang diperoleh sebanyak 103 ekor.
3. Jumlah Lalat Yang Terperangkap Dengan Menggunakan Fly Trap Berbentuk Bulat Dengan Umpan Udang Basah, Insang Ikan Dan Ampas Tebu

Tabel 4.3 Hasil pengamatan jumlah lalat yang terperangkap pada Fly trap berbentuk bulat

\begin{tabular}{|c|c|c|c|}
\hline Umpan & $\begin{array}{c}\text { Hari dan } \\
\text { pengulangan }\end{array}$ & $\begin{array}{c}\text { Jumlah } \\
\text { lalat }\end{array}$ & Rata-rata \\
\hline \multirow[t]{3}{*}{$\begin{array}{l}\text { Udang } \\
\text { basah }\end{array}$} & $\begin{array}{c}\text { Hari 1- } \\
\text { pengulangan } 1\end{array}$ & 135 & \multirow[t]{3}{*}{$353 / 3=118$} \\
\hline & $\begin{array}{c}\text { Hari 2- } \\
\text { pengulangan } 2\end{array}$ & 120 & \\
\hline & $\begin{array}{c}\text { Hari 3- } \\
\text { pengulangan } 3\end{array}$ & 98 & \\
\hline \multirow{3}{*}{$\begin{array}{l}\text { Insang } \\
\text { ikan }\end{array}$} & $\begin{array}{c}\text { Hari 4- } \\
\text { pengulangan } 1\end{array}$ & 208 & \multirow[t]{3}{*}{$518 / 3=173$} \\
\hline & $\begin{array}{c}\text { Hari 5- } \\
\text { pengulangan } 2\end{array}$ & 189 & \\
\hline & $\begin{array}{c}\text { Hari 6- } \\
\text { pengulangan } 3\end{array}$ & 121 & \\
\hline \multirow[t]{3}{*}{$\begin{array}{c}\text { Ampas } \\
\text { tebu }\end{array}$} & $\begin{array}{c}\text { Hari 7- } \\
\text { pengulangan } 1\end{array}$ & 101 & \multirow[t]{3}{*}{$245 / 3=82$} \\
\hline & $\begin{array}{c}\text { Hari 8- } \\
\text { pengulangan } 2\end{array}$ & 74 & \\
\hline & $\begin{array}{c}\text { Hari 9- } \\
\text { pengulangan } 3\end{array}$ & 70 & \\
\hline
\end{tabular}

Berdasarkan tabel 4.3 menunjukkan bahwa pada hari ke-1 s/d ke-3 rata-rata jumlah lalat yang masuk ke Fly trap yang berbentuk bulat dengan umpan udang basah adalah sebanyak 118 ekor, pada hari ke-4 s/d ke-6 dengan umpan insang ikan rata- rata yang diperoleh sebanyak 173 ekor, sedangkan pada hari ke-7 s/d hari ke-9 menggunakan ampas tebu rata- rata yang diperoleh sebanyak 82 ekor.

\section{Hasil Uji Anova}

Pengambilan hasil uji Anova ditentukan dengan melihat nilai probabilitas, apabila probabilitas $>0,05$, maka $\mathrm{HO}$ diterima. Apabila probabilitas < 0,05 maka H0 ditolak, berikut merupakan hasil uji Anova

Tabel 4.4 Hasil Uji Anova

\begin{tabular}{|c|c|c|c|c|}
\hline $\begin{array}{c}\text { Berbagai Perangkap } \\
\text { Dan Umpan }\end{array}$ & Mean & $\begin{array}{c}\text { Std } \\
\text { Deviation }\end{array}$ & Std Error & Sig \\
\hline Kubus + Udang & & & & \\
Basah & 146,67 & 21,197 & 12,238 & \\
Segitga + Udang & 122,33 & 21,595 & 12,468 & \\
Basah & 117,67 & 18,610 & 10,745 & \\
Bulat + Udang & 381,33 & 151,163 & 87,274 & \\
Basah & 210,67 & 56,323 & 32,518 & \\
Kubus + Insangikan & 172,67 & 45,742 & 26,409 & \multirow{2}{*}{0,001} \\
Segitiga + Insang & 115,67 & 10,214 & 5,897 & \\
Ikan & 102,67 & 18,717 & 10,806 & \\
Bulat + Insang Ikan & 81,67 & 16,862 & 9,735 & \\
Kubus + Ampas & & & & \\
Tebu & & & & \\
Segiiga + Ampas & & & 19,233 & \\
Tebu & 161,26 & 99,936 & & \\
Bulat + Ampas & & & & \\
Tebu & & & & \\
Total & & & & \\
\hline
\end{tabular}


Dari tabel 4.4 diatas, diketahui bahwa $\mathrm{F}$ hitung pada uji Anova diatas adalah 7.489 dengan probabilitas 0.001. karena nilai $\mathrm{p}<0.05$ maka H0 ditolak. Hal ini menunjukkan bahwa ada pengaruh berbagai Flytrap dan umpan dalam pengendalian kepadatan lalat.

\section{PEMBAHASAN}

\section{Pengaruh Berbagai Fly trap Yang Berbentuk Kubus, Segitiga dan Bulat Terhadap Jumlah Lalat Yang Terperangkap}

Dari hasil penelitian yang dilakukan selama 9 hari diperoleh bahwa jumlah lalat rumah yang masuk kedalam Fly trap semakin hari semakin menurun. Dari ketiga bentuk Fly trap, bentuk yang paling disenangi lalat adalah Fly trap berbentuk kubus, jumlah lalat yang masuk dari ketiga umpan adalah 1988 ekor dengan ratarata 663 ekor. Jumlah lalat yang masuk dengan umpan udang basah adalah sebanyak 382 dengan rata-rata 127 ekor, dengan menggunakan insang ikan yaitu sebanyak 1144 ekor dengan rata-rata 381 ekor, sedangkan dengan umpan ampas tebu jumlah lalat yang terperangkap adalah 461 ekor dengan rata-rata 107 ekor.

Fly trap berbentuk kubus sangat disukai lalat karena bentuknya yang memiliki banyak sudut sehingga jika lalat masuk kedalam perangkap tempat yang dituju adalah sudut setiap perangkap. Pada penelitian ini ditemukan bahwa tempat yang disukai lalat untuk dihinggapi adalah sudut yang paling atas dan sisi atas kubus. Menurut Budiman dan Suryono (2011) lalat sering hinggap ditempat yang memanjang vertikal misalnya tali yang menggantung, dan jarang mau hinggap di dinding.

Hasil penelitian ini tidak sesuai dengan hasil penelitian yang dilakukan oleh Agus (2013) bahwa dari beberapa bentuk perangkap, perangkap yang paling disenangi lalat adalah perangkap yang berbentuk bola dengan rata- rata 79,25 ekor dan silinder sebanyak 78,25 ekor. Lalat buah pada perangkap berbentuk selinder banyak didekati oleh lalat jantan karena kedua bentuk perangkap tersebut tertarik pada warna kuning dari perangkap tersebut.

Efektifitas pengendalian lalat dengan menggunakan Fly trap dapat menurunkan tingkat kepadatan lalat. Selama ini pengendalian lalat pada umunya menggunakan bahan insectisida. Tetapi setelah dilakukan penelitian dengan pemasangan Fly trap terjadi penurunan yang drastis dari hari-kehari. Menurut Azwar (1995) bahwa kebiasaan lalat sangat tertarik pada makanan yang dimakan oleh manusia sehari-hari.

Menurut Depkes 2008 bahwa lalat merupakan serangga yang bersifat fototropik, yaitu menyukai sinar, oleh sebab itu diciptakanlah sebuah alat dimana umpan diletakkan dibawah kerucut bersinar yang dingdingnya terbuat dari kawat kasa, apabila lalat memakan umpan setelah kenyang terbang kearah vertikal/arah dimana asal sinar/cahaya. Tetapi ruangan yang terang tersebut telah terkurung oleh dingding dari kawat kasa, disinilah lalat telah terperangkap di dalam Fly trap.

Menurut direktorat jenderal pemberantas penyakit menular dan penyehatan lingkungan pemukiman
(Depkes, 2008) dalam petunjuk teknis pemberantas lalat menyatakan perilaku lalat suka hidup berkelompok dan tidak suka terbang terus-menerus, dari perilaku inilah yang menyebabkan lalat mudah terjebak perangkap yang sengaja di pasang manusia.

Berdasarkan sifat-sifat lalat tersebut dapat disimpulkan bahwa pengguaan Fly trap pada pembuangan sampah sangat tepat karena masyarakat di sekitar pembuangan sampah sudah mengeluh dengan tempat pembuangan sampah yang ada di budi luhur, karena sebenarnya tempat pembuangan sampah tersebut adalah lahan milik masyarakat yang tidak ditempati.

\section{Pengaruh Berbagai Jenis Umpan (Udang Basah, Insang Ikan, Ampas Tebu) Terhadap Jumlah Lalat Yang Masuk Kedalam Fly trap.}

Dari ketiga umpan yang digunakan selama sembilan hari di peroleh hasil yang berbeda-beda dan semakin hari- semakin menurun seperti dari hari ke1s/dke-3 dengan memakai umpan udang basah diperoleh hasil 1160 ekor (dari 3 perangkap). Dengan mamakai umpan insang ikan diperoleh 2294 ekor dari hari ke-4s/d ke-6 dengan ketiga perangkap, sedangkan dengan memakai umpan ampas tebu yang dilakukan dari hari ke7s/d ke-9 diperoleh 1014 ekor lalat. Dari ketiga umpan tersebut umpan yang paling disenangi lalat adalah umpan insang ikan.

Insang ikan sangat disukai lalat karena insang ikan mengandung darah, baunya sangat khas dan menyengat. Lalat juga menyukai makanan yang sedang mengalami proses fermentasi/pembusukan dan lalat sangat menyukai makanan yang cair atau makanan yang basah.

Sedangkan peneliti sebelumnya yaitu Nadaek (2015) umpan yang sangat disukai lalat adalah udang basah yaitu dengan jumlah lalat yang terperangkap sebanyak 1374 ekor, lalat banyak terperangkap karena aroma khas dan adanya bau dari kotoran pada bagian kepala yang dikeluarkan dari udang yang menarik lalat tersebut dan juga adanya kandungan sumber protein asam lemak. Selain itu udang juga merupakan sumber protein yang sangat baik dan selenium. Sumber penghasil zat besi, omega-3, asam lemak, seng, tembaga, magnesium, niasin serta vitamin B12 dan Vitamin D (Nadeak,2015).

Dari hasil penelitian yang dilakukan umpan basah juga disukai lalat dan hanya memiliki perbandingan yang sedikit dari ketiga perangkap jumlah lalat yang masuk kedalam perangkap adalah sebanyak 1160 dengan rata-rata 387 ekor.

Sedangkan dengan memakai ampas tebu lalat yang terperangkap semakin berkurang jumlah lalat yang terperangkap hanya 1014 ekor dengan rata-rata 338 ekor berbeda dari umpan sebelumnya. Lalat kurang menyukai ampas tebu karena tidak memiliki bau yang menyengat tetapi ampas tebu merupakan makanan yang manis.

Menurut Aini (2012) ampas tebu digunakan sebagai umpan umpan dalam menggunakan Fly trap karena ampas tebu marupakan makanan yang manis, dan lalat sangat menyukai makanan yang dimakan oleh manusia seperti gula, susu. Dengan menggunakan ampas tebu juga tidak membahayakan terhadap masyarakat 
karena dengan memakai ampas tebu akan memiliki 2 keuntungan yaitu dapat menurunkan tingkat kepadatan lalat dan selain itu tebu juga dapat dimanfaatkan untuk minuman kelurga sebelum ampas tebu digunakan sebagai umpan.

Jadi dari hasil penelitian yang dilakukan bahwa perangkap Fly trap sangat efektif digunakan dalam pengendalian lalat, selain perangkap mudah di buat, Fly trap ini sangat sederhana dan tidak menimbulkan efek samping. Dan dari hasil penelitian yang dilakukan Fly trap yang paling efektif adalah Fly trap berbentuk kubus dan umpan yang paling disukai oleh lalat adalah insang ikan.

Berdasarkan hasil uji oneway anova nilai $p=0.001<0.05)$, dapat diartikan bahwa secara statistik H0 ditolak, maka dapat disimpulkan bahwa ada pengaruh berbagai Fly trap (kubus, segitiga dan bulat) dan umpan (udang basah, insang ikan dan ampas tebu) dalam pengendalian lalat secara efektif.

\section{Hasil Pengukuran Temperatur}

Pada saat penelitian dilakukan pengukuran temperatur dilakukan 3 kali pengukuran per hari yaitu pagi jam 08.00, siang jam12.00 dan sore jam 16.00, penelitian dilakukan selama sembilan hari, pengukuran temperatur diukur dengan menggunakan higrometer, dinyatakan dalam derajat Celcius $\left({ }^{0} \mathrm{C}\right)$ dan rata-rata yang didapat adalah $30^{\circ} \mathrm{C}-31^{\circ} \mathrm{C}$.

Sedangkan menurut Sucipto, 2011 jumlah lalat akan meningkat pada suhu $20^{\circ} \mathrm{C}-25^{\circ} \mathrm{C}$ dan akan berkurang jumlah pada suhu $<10^{\circ} \mathrm{C}$ atau $>49^{\circ} \mathrm{C}$ dan untuk istirahat lalat memerlukan suhu $35^{\circ} \mathrm{C}-40^{\circ} \mathrm{C}$.

Dari hasil penelitian temperatur di pembuangan sampah di jalan budi luhur dapat dikatakan sesuai karena pada temperatur $30^{\circ} \mathrm{C}-31{ }^{0} \mathrm{C}$ jumlah lalat masih dapat dikatakan meningkat.

\section{Hasil Pengukuran Kelembapan}

Rata - rata yang diperoleh pada saat penelitian yang dilakukan di pembuangan sampah jalan budi luhur adalah 51,8\%-52,2\%, pengukuran dilakukan dengan menggunakan Hygrometer, dan dinyatakan dalam persen $(\%)$

Menurut Sucipto, 2011 kelembaban erat hubungannya dengan temperatur setempat. Bila temperatur tinggi maka kelembaban rendah, dan bila temperatur rendah maka kelembapan akan semakin tinggi. Kelembaban yang disukai lalat adalah $90 \%$.

\section{Kecepatan Angin}

Alat ukur yang digunakan untuk mengukur kecepatan angin adalah Anemometer,dan dinyatakan dalam satuan meter per detik $(\mathrm{m} / \mathrm{d})$. Kecepatan angin pada saat penelitian di tempat pembuangan sampah jalan Budi Luhur adalah $0,9 \mathrm{~m} / \mathrm{d}$.

Menurut Depkes, 1992 lalat sangat aktif mencari makanan pada angin yang tenang dan sepoi-sepoi menurut skala Beufort yaitu berkisar 0,3-1,5 m/d, tetapi lalat dewasa akan mengurangi aktivitasnya pada angin kencang. Angin juga akan mempengaruhi istrahat lalat, lalat akan menghindarkan diri dari tempat-tempat angin kencang.

\section{Kesimpulan}

Dari hasil pembahasan diatas dapat disimpulkan sebagai berikut:

1. Dari ketiga bentuk Fly trap (Bentuk kubus, segitiga dan bulat) yang paling disenangi lalat adalah Fly trap yang berbentuk Kubus.

2. Dari ketiga jenis umpan (udang basah, insang ikan dan ampas tebu) umpan yang paling banyak masuk kedalam perangkap lalat adalah Insang ikan dengan rata- rata dari ketiga bentuk Fly trap adalah 765 ekor.

3. Hasil uji one way anova menunjukkan bahwa ada perbedaan berbagai Fly trap berbentuk kubus, segitiga dan bulat dengan umpan udang basah, insang ikan dan ampas tebu dalam pengendalian lalat.

4. Hasil uji Tukey menujukkan bahwa fly trap dan umpan yang efektif dalam pengendalian lalat adalah Fly trap berbentuk kubus dengan Umpan insang ikan .

5. Penggunaan Fly trap sangat efektif dalam pengendalian lalat di pembuangan sampah budi luhur.

2. Saran

1. Untuk menurunkan tingkat kepadatan populasi lalat perlu kesadaran masyarakat dalam memperbaiki keadaan sanitasi lingkungan.

2. Diharapkan masyarakat dapat membuat Fly trap untuk menurunkan kepadatan lalat khususnya di pemukiman yang berada di sekitar pembuangan sampah budi luhur.

3. Bagi peneliti selanjutnya dapat meneliti apakah ada hubungan perbedaan jam 08:00 - 12:00 dan 13:00-17:00 wib dengan jumlah lalat yang masuk ke dalam Fly trap.

\section{DAFTAR PUSTAKA}

Aini, Natijtul, 2000, Efektifitas penggunaan tingkat kepadatan populasi lalat di Desa Namo Bintang kecamatan Pancur Batu Kabupaten Deli Serdang, Skripsi Fakultas Kesehatan Masyarakat. Universitas Sumatera Utara. Medan

Budiman, Suryono, 2011, Ilmu Kesehatan Masyarakat Dalam Konteks Kesehatan Lingkungan, Jakarta : EGC.

Depkes RI, 1992, Pedoman Tehnis Pengendalian Lalat, Dit. Jen.PPM dan PLP, Jakarta.

Depkes RI. 2008. Pedoman Pengendalian Lalat Di Pelabuhan. Jakarta: Direktorat Jenderal Pengendalian Penyakit Dan Penyehatan Lingkungan.

Ditjen PP\&PL Kemenkes RI.2014. Pedoman Pengendalian Lalat

Nadeak dkk,2015. Efektifitas variasi umpan dalam penggunaan Fly Trap di tempat penggunaan ahir ganet kota tanjung pinang, Tanjung pinang: Universitas Negeri Andalas. 
Notoatmodjo,Soekidjo,2010,"Metode Penelitian Kesehatan",Edisi Revisi,Rineka Cipta, Jakarta.

Peraturan Menteri Kesehatan no 376/ Menkes/ Per III. 2010. Tentang Pengendalian Vektor

Panggabean, Roni.2014.Efektifitas Warna Fly Trap Dengn Umpan Udang Basah Terhadap Jumlah Tertangkapnya Lalat Rumah (Musca Domestika) Di Kelurahan Dwikora Kecamatan Medan Helvetia Tahun 2014Skripsi. Program Studi Kesehatan Masyarakat Peminatan Kesehatan Lingkungan Fakultas Farmasi dan ilmu Kesehatan Universitas Sari Mutiara Indonesia

Saepuddin M. 2011. Metodologi Penelitian Kesehatan Masyarakat. Jakarta: CV. Trans Info Media

Santi, Devi Nuraini, 2001, "Manajemen Pengendalian Lalat", Fakultas Kedokteran. Universitas Sumatera Utara, Medan.

Sembel, Dantje T. 2009. Entomologi kesehatan. Yogyakarta: Andi
Soedarto. 2013. Lingkungan Kesehatan, jakarta. Sagung Seto

Sriasi dkk, 2000. Parasitologi Kedokteran. Jakarta: Balai Penerbit FKUI.

Sucipto, Cecep dani. 2011. Vektor Penyakit Tropis. Yogyakarta: Gosyen Publishing.

Sumantri, Arif. 2015. "Kesehatan Lingkungan", Edisi Revisi, Kencana Predana Media Group, Jakarta.

Suprapto, 2003, “Efektifitas Pengendalian Lalat Rumah (Musca Domestica) Dengan Menggunakan Fly Trap Pada Parameter Kantor Pelabuhan Dumai”, Skripsi, Kesehatan Masyarakat, Universitas Sumatera Utara, Medan.

Susana, Dewi. 2011. Entomologi Kesehatan. Jakarta : Universitas Indonesia (press)

Ungguh, Jasa Muliawan, 2011. “Buku Pintar Binatang”, Cetakan Pertama, Harmoni Diva Group, Jakarta.

Wikipedia, 2007. Lalat. http://id.wikipedia.org/wiki/Lalat. Diakses tanggal 3 Februari 2016. 